\title{
Kadar Protein pada Produk Substitusi Tepung Mocaf (Cookies, Mi, Brownies, Nugget Ayam)
}

\author{
Febi Nurhanifah $^{\mathrm{a}, 1,{ }^{*}}$, Najib Tuisina Naenum ${ }^{\mathrm{b}, 2}$, Silviwanda $^{\mathrm{b}, 3}$, Zahra Azkia $^{\mathrm{b}, 4}$ \\ ${ }^{a}$ Universitas Pendidikan Indonesia, Jl. Dr. Setiabudi No. 229, Isola, Kota Bandung, 40154, Indonesia \\ ${ }^{\mathrm{b}}$ Universitas Pendidikan Indonesia, Jl. Dr. Setiabudi No. 229, Isola, Kota Bandung, 40154, Indonesia \\ ${ }^{1}$ febinurhanifah@upi.edu*; ${ }^{2}$ najibtuisinan@upi.edu; ${ }^{3}$ silviw@upi.edu ${ }^{4}$ zahraazkia@upi.edu \\ *penulis korepondensi
}

\begin{abstract}
Mocaf flour (Modified Cassava Flour) is a modified cassava flour using Lactic Acid Bacteria (LAB) through a fermentation process. The protein content of food products based on mocaf flour can be increased by adding other ingredients with high protein content. This study aims to determine and compare the best alternatives in increasing protein content in these products. The methodology used in this study is a literature review with a descriptive type of analysis. The protein content produced in mocaf processed products included mocaf cookies with tempeh flour of $9.09 \pm$ $0.22 \%$, mocaf noodle products with catfish flour of $14.65 \pm 0.19 \%$, and brownie products with koro flour of $8.73 \%$, and the chicken nuggets product with the addition of cartilage flour of $18.70 \%$.
\end{abstract}

Keywords: brownies, chicken nugget, cookies, mocaf, noodle, substitution

\section{ABSTRAK}

Tepung mocaf (Modified Cassava Flour) merupakan hasil modifikasi tepung ubi kayu menggunakan Bakteri Asam Laktat (BAL) melalui proses fermentasi. Kandungan protein pada produk pangan berbasis tepung mocaf dapat ditingkatkan dengan menambahkan bahan lain yang berkadar protein tinggi. Penelitian ini bertujuan untuk mengetahui dan membandingkan alternatif terbaik dalam meningkatkan kadar protein pada produk tersebut. Metodologi yang digunakan dalam penelitian ini adalah literature review dengan jenis analisis deskriptif. Kadar protein yang dihasilkan pada produk olahan mocaf di antaranya yaitu produk cookies mocaf dengan tepung

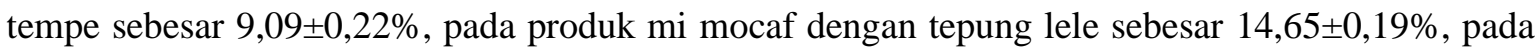
produk brownies dengan tepung koro sebesar $8,73 \%$, dan pada produk nugget ayam dengan penambahan tepung tulang rawan sebesar $18,70 \%$.

Kata Kunci: brownies, cookies, mi, mocaf, nugget ayam, substitusi

\section{Pendahuluan}

Dewasa ini, kebutuhan terhadap tepung terigu di Indonesia semakin meningkat. Menurut Hersoelistyorini et al. (2015), peningkatan kebutuhan terigu Indonesia ini lama kelamaan akan memberatkan devisa negara. Tepung terigu banyak dimanfaatkan untuk membuat aneka kudapan, beberapa di antaranya yaitu cookies, mie, brownies, dan lainnya. Dalam rangka mengurangi ketergantungan Indonesia terhadap impor terigu, maka upaya optimalisasi pemanfaatan sumber pangan lokal perlu dilakukan.

Sebagai negara agraris, Indonesia kaya akan sumber pangan tinggi karbohidrat. Salah satu komoditi pangan sumber karbohidrat yang melimpah di Indonesia adalah ubi kayu. Produksi ubi kayu di Indonesia pada tahun 2018 adalah sebesar 19.341.233 ton. Provinsi 
Lampung menjadi daerah penghasil singkong terbesar se-Indonesia dengan jumlah 6.683.758 ton (Badan Pusat Statistik, 2018).

Bagian daging ubi kayu dapat diolah menjadi beberapa jenis tepung, yaitu tepung gaplek, tepung tapioka/cassava, dan tepung mocaf (Modified Cassava Flour). Menurut Subagio (2008), tepung mocaf (Modified Cassava Flour) merupakan hasil modifikasi tepung ubi kayu melalui proses fermentasi menggunakan Bakteri Asam Laktat (BAL) dan memiliki karakteristik yang lebih baik dibanding tepung ubi kayu, yaitu nilai viskositas, kemampuan gelasi, daya rehidrasi dan kelarutan yang meningkat.

Proses pembuatan tepung mocaf menghasilkan tepung yang secara karakteristik dan kualitas hampir menyerupai tepung terigu (Subagio, 2007) sehingga dapat digunakan sebagai bahan pengganti terigu atau campuran terigu 30\% - 100\% (Yuliyandjaja, 2020). Kandungan gizi pangan perlu dipertahankan dan difortifikasi agar bermanfaat bagi keseimbangan proses metabolisme dalam tubuh manusia. Salah satu kandungan gizi yang perlu diperhatikan dalam produk pangan adalah kadar proteinnya. Namun, kadar protein pada tepung mocaf sebagian besar hilang selama proses fermentasi sehingga kadar protein tepung mocaf hanya sebesar 1\% (Subagio 2008).

Protein merupakan suatu zat makanan yang amat penting bagi tubuh karena zat ini di samping berfungsi sebagai bahan bakar dalam tubuh juga berfungsi sebagai zat pembangun dan pengatur (Syarief dan Anies, 1988). Namun, kadar protein pada tepung mocaf lebih rendah sehingga konsumsinya perlu didampingi oleh bahan pangan lain yang berprotein tinggi seperti telur dan tepung terigu (Winarno, 2009). Menurut Naurah (2013) di antara produk nabati lainnya, kacang-kacangan mempunyai peranan cukup besar dalam pemenuhan protein pada tubuh.

Dengan ditambahkannya bahan lain untuk menunjang kadar protein pada pembuatan produk pangan mocaf, maka dapat dikatakan bahwa produk tersebut merupakan produk inovasi pangan. Hal ini sesuai dengan pernyataan Bappenas (2007) bahwa penganekaragaman pangan atau diversifikasi pangan adalah upaya peningkatan konsumsi aneka ragam pangan dengan prinsip gizi yang seimbang. Inovasi pangan akan terus berkembang di Indonesia sebagai salah satu usaha penganekaragaman pangan.

Oleh karena itu, perlu adanya kajian mengenai kadar protein pada produk olahan berbasis tepung mocaf dengan substitusi bahan lain untuk mengetahui dan membandingkan alternatif terbaik dalam meningkatkan kadar protein pada produk tersebut sehingga dapat mengurangi penggunaan tepung terigu.

\section{Metode Penelitian}

\subsection{Jenis Penelitian}

Desain penelitian yang digunakan adalah literature review atau tinjauan pustaka. Literature review merupakan metode yang digunakan untuk mengumpulkan data dan sumber-sumber yang terkait dengan topik atau tema yang akan dibahas dalam suatu penulisan. Adapun sifat dari penelitian ini adalah analisis deskriptif, yaitu penguraian data secara teratur yang telah diperoleh dan diberikan pemahaman serta penjelasan agar dapat dipahami dengan baik oleh pembaca. 


\subsection{Kriteria Inklusi dan Eksklusi}

a. Kriteria Inklusi

1) Artikel penelitian terbitan tahun 2013-2020

2) Artikel yang memuat penelitian produk mocaf

b. Kriteria Eksklusi

1) Artikel penelitian yang tidak bisa diakses dengan lengkap

\subsection{Strategi Pencarian Literatur}

Penelusuran artikel publikasi pada google, dan google scholar menggunakan kata kunci yang dipilih yaitu tepung mocaf, cookies, mi, brownies, nugget ayam, dan protein.

\subsection{Analisis dan Sintesis}

Analisis data adalah proses mencari dan menyusun secara sistematis data yang diperoleh dari hasil wawancara, catatan lapangan, dan dokumentasi (Sugiyono, 2015: 335). Dalam hal penelitian, analisis adalah langkah yang di tempuh setelah data penelitian terkumpul. Sintesis merupakan paduan berbagai pengertian atau hal sehingga merupakan kesatuan yang selaras atau penentuan hukum yang umum berdasarkan hukum yang khusus (KBBI, 2003).

Hasil sintesis pada dasarnya berupa data atau informasi yang belum pernah ditulis. Metode yang digunakan pada beberapa artikel yang disintesis adalah naratif dengan cara dikelompokkan sesuai data yang telah diekstrasi sehingga jurnal dapat sesuai dengan kriteria inklusi dan eksklusi. Selanjutnya dilakukan analisis terhadap isi jurnal yang memuat tujuan dan hasil penelitian.

\section{Hasil dan Pembahasan}

Tepung mocaf merupakan salah satu bentuk inovasi tepung dari ubi kayu yang telah banyak dimanfaatkan pada produk pangan. Saat ini penggunaan mocaf sudah mulai dijadikan alternatif pengganti tepung terigu dengan kandungan yang tidak berbeda jauh. Adapun produk pangan yang dapat disubstitusi dengan tepung mocaf di antaranya yaitu:

\subsection{Cookies Tepung Mocaf}

Cookies merupakan salah satu makanan ringan sejenis biskuit yang terbuat dari adonan lunak, bertekstur renyah dan apabila dipatahkan tampak tidak padat (Badan Standardisasi Nasional, 2011). Menurut Widiantara (2018), hal yang harus diperhatikan dalam pengolahan cookies adalah kerenyahan. Salah satu faktor yang mempengaruhi kerenyahan dan kualitas akhir cookies adalah jenis tepung. Umumnya tepung terigu merupakan bahan yang sering digunakan dalam pembuatan cookies.

Tepung terigu yang merupakan bahan dasar pembuatan cookies memiliki keistimewaan, yaitu kemampuannya untuk membentuk gluten yang bersifat elastis pada saat dibasahi dengan air. Sifat elastis gluten pada adonan menyebabkan kue tidak mudah rusak ketika dicetak (Turisyawati, 2011). Dalam pembuatan cookies, tepung yang biasa digunakan adalah tepung terigu jenis soft wheat, yaitu tepung terigu yang mempunyai kandungan protein rendah 7,5-8\%. Tepung terigu memiliki kandungan gluten yang rendah sehingga 
jenis terigu soft wheat ini sangat cocok dalam pembuatan cookies yang tidak memerlukan proses kekenyalan atau pengembangan produk.

Apabila merujuk pada penelitian Oktaviana, Hersoelistyorini dan Nurhidajah (2017), semakin tinggi penggunaan tepung mocaf maka dapat menyebabkan penurunan daya kembang dan kandungan protein pada cookies. Menurut SNI 2973-2011, protein merupakan salah satu nilai gizi yang digunakan dalam penentuan syarat mutu cookies. Untuk melengkapi kandungan cookies mocaf maka perlu adanya substitusi lain sebagai penunjang.

Tabel 3.1 Literatur tentang Persentase Kadar Protein pada Cookies dengan Berbagai Jenis Substitusi

\begin{tabular}{|c|c|c|}
\hline Sumber & Jenis Cookies & Kadar Protein $(\%)$ \\
\hline Kristanti, et al. (2015) & $\begin{array}{l}\text { Cookies mocaf dengan tepung } \\
\text { tempe }\end{array}$ & $9,09 \pm 0,22$ \\
\hline Khalil (2006) & $\begin{array}{l}\text { Cookies mocaf dengan tepung } \\
\text { kacang hijau }\end{array}$ & 6,17 \\
\hline Alvionita, et al. (2017) & $\begin{array}{l}\text { Cookies mocaf dengan tepung } \\
\text { beras pecah kulit }\end{array}$ & 5,2 \\
\hline Herawati, et al. (2018) & $\begin{array}{l}\text { Cookies mocaf dengan tepung } \\
\text { beras merah dan kayu manis }\end{array}$ & 2,87 \\
\hline
\end{tabular}

Apabila merujuk pada Tabel 3.1, terdapat beberapa jenis cookies mocaf dengan penambahan bahan lainnya. Cookies mocaf dengan penambahan tepung tempe memiliki kadar protein lebih tinggi dibandingkan penambahan lainnya. Menurut Kristanti et al. (2015), cookies mocaf dengan tepung tempe memiliki kadar protein $(9,09 \pm 0,22 \%)$ dengan perbandingan sebesar 75:25. Peningkatan rasio pemberian tepung tempe menyebabkan peningkatan kandungan protein dan lemak cookies. Kandungan protein tempe cukup tinggi, dimana protein pada tempe segar sebesar $18,3 \%$ sedangkan pada tepung tempe sebesar 48,75\% (Rahayu et al., 2015).

Sementara cookies mocaf dengan penambahan tepung kacang hijau memiliki kadar protein tertinggi kedua setelah cookies mocaf dengan tepung tempe. Hal ini sesuai yang dikemukakan Khalil (2006) bahwa komponen terbesar kedua yang terdapat pada kacang hijau setelah karbohidrat adalah protein dengan kualitas baik seperti jenis kacang-kacangan pada umumnya. Menurut penelitian Mahardika (2015), penambahan tepung kacang hijau pada proses pembuatan cookies mocaf dalam 1 porsi (5 keping: 35 gram) diperoleh kandungan protein tertinggi, yaitu 2,16 gram dengan takaran $60 \%$ tepung mocaf dan $40 \%$ tepung kacang hijau. Apabila diubah ke dalam satuan persentase maka kadar protein yang diperoleh adalah $6,17 \%$.

Cookies mocaf dengan penambahan tepung beras pecah kulit juga tidak jauh berbeda kadar proteinnya dengan cookies mocaf dengan tepung kacang hijau. Apabila merujuk penelitian Alvionita, et al. (2017) bahwa cookies yang terbuat dari 50\% tepung mocaf dan $50 \%$ tepung beras pecah kulit yang paling disukai panelis diperoleh jumlah konsentrasi nilai hasil analisis protein sebesar 5,2\%. Menurut Welli (2012), penggunaan tepung mocaf dan tepung beras pecah kulit dalam pembuatan cookies memiliki kadar protein lebih 
rendah dibandingkan tepung terigu. Sama hal dengan tepung beras pecah kulit mengandung kadar protein yang lebih kecil dibandingkan kandungan pati karena pati merupakan penyusun utama beras (Haryadi, 2006).

Adapun jenis cookies mocaf dengan penambahan tepung beras merah dan kayu manis diperoleh kadar protein sebesar 2,87\% dengan rasio tepung beras merah 3: tepung mocaf 1 : konsentrasi kayu manis 0,5\% yang disukai panelis (Herawati et al., 2018). Kadar protein cenderung meningkat seiring dengan semakin meningkatnya penggunaan tepung beras merah. Hal tersebut disebabkan karena tepung beras merah mengandung protein sebesar 9,4\% (Departemen Kesehatan Republik Indonesia, 2009), sedangkan tepung mocaf mengandung kadar protein sebesar 3,42\% (Maulida, 2016) sehingga peningkatan jumlah tepung beras merah akan meningkatkan kadar protein cookies.

\subsection{Mi Tepung Mocaf}

Mi merupakan salah satu jenis makanan yang terbuat dari tepung. Umumnya tepung yang digunakan adalah tepung terigu. Menurut Ramadhan (2015), tepung mocaf dapat dijadikan bahan campuran pendamping tepung terigu pada pembuatan mi. Proses pembuatan tepung mocaf menghasilkan tepung yang secara karakteristik dan kualitas hampir menyerupai tepung terigu (Subagio, 2007) sehingga dapat digunakan sebagai bahan pengganti terigu atau campuran terigu 30\%-100\% (Yuliyandjaja, 2020). Mi mocaf dapat mensubstitusi tepung terigu hingga tingkat substitusi $15 \%$ pada produk mi bermutu tinggi dan hingga 25\% untuk mi bermutu rendah (Indrianti, 2013).

Mutu terigu yang dikehendaki dalam pembuatan mi kering adalah terigu yang memiliki kadar air 14\%, kadar protein 8-12\%, kadar abu 0,25-0,60\%, dan gluten basah 24-36\% (Suyanti, 2010). Sedangkan kadar protein tepung mocaf sebagian besar hilang selama proses fermentasi, sehingga kadar protein tepung mocaf hanya sebesar $1 \%$ menurut Subagio (2008). Oleh karena itu, perlu usaha untuk meningkatkan kandungan proteinnya, antara lain dengan penambahan tepung lele, tepung ubi jalar, tepung jagung, dan tepung ampas tahu.

Tabel 3.2 Literatur tentang Persentase Kadar Protein pada Mi dengan Berbagai Jenis Substitusi

\begin{tabular}{llc}
\hline \multicolumn{1}{c}{ Sumber } & \multicolumn{1}{c}{ Jenis Mi } & Kadar Protein (\%) \\
\hline Aliya (2016) & Mi mocaf dengan tepung lele & $14,65 \pm 0,19$ \\
Nurjannah (2019) & Mi mocaf dengan tepung ubi jalar & 9,77 \\
Setiavani (2013) & Mi mocaf dengan tepung ampas tahu & 3,81 \\
Diniyah (2018) & Mi mocaf dengan tepung jagung & $2,95 \pm 0,12$ \\
\hline
\end{tabular}

Apabila merujuk pada Tabel 3.2, menurut Aliya (2016), pengujian mi dengan penggunaan $25 \%$ terigu, $40 \%$ mocaf, $20 \%$ tapioka, dan $15 \%$ tepung lele menghasilkan kadar protein sebesar $14,65 \pm 0,19 \%$. Hasil uji statistik One Way ANOVA pada tingkat kepercayaan $95 \%$ menunjukkan bahwa penambahan tepung mocaf dan tepung lele memberikan pengaruh yang signifikan $(\mathrm{p}=0,000)$ terhadap kadar protein mi kering. Dari hasil pengujian ini mi kering yang dibuat sudah sesuai dengan kadar protein minimal 
pada SNI 01-2974-1996, yaitu 11\% sehingga kadar gizi meningkat dibanding mi mocaf standar.

Pada penelitian yang dilakukan oleh Nurjannah (2019), pembuatan mi basah mocaf dengan tambahan tepung ubi jalar ungu menghasilkan mi yang mengandung kadar protein 9,77\%. Kadar ini telah memenuhi syarat mutu kandungan protein mi basah menurut SNI 2987-2015 yaitu 6\%. Kadar protein pada penelitian ini juga dipengaruhi kandungan telur yang ditambahkan pada saat proses pembuatan mi.

Berdasarkan penelitian Setiavani (2013), kadar protein tertinggi sebesar 3,81\% didapat dari perlakuan kombinasi tepung terigu:tepung mocaf: tepung ampas tahu fermentasi dengan masing-masing sebesar 350 gr:50 gr:150 gr. Penambahan tepung ampas tahu fermentasi sedikit berpengaruh pada peningkatan kadar protein mie basah. Hal ini karena tepung ampas tahu fermentasi memiliki kadar protein sebesar 4,33\% (Setiavani, 2013). Kadar protein mi basah ini telah memenuhi syarat mutu kandungan protein mi basah menurut SNI 2987-2015 yaitu 6\%.

Berdasarkan penelitian Diniyah (2018), kadar protein mi mocaf dengan substitusi tepung jagung diperoleh $2,953 \pm 0,12 \%$. Apabila kadar protein tersebut dibandingkan dengan mi kontrol yang komposisinya tepung terigu $100 \%$ terdapat perbedaan yang signifikan karena kadar protein pada mi kontrol lebih besar yaitu 10,288 $\pm 0,01 \%$. Hal ini disebabkan oleh kandungan protein tepung terigu yang lebih besar dibandingkan mocaf maupun tepung jagung. Kandungan protein pada terigu sebesar 13\% (Fitasari, 2009) sementara tepung jagung mengandung protein sebesar 8,0\% (Muhandri, 2012). Mocaf memiliki kadar protein yang lebih rendah maksimal 1,0\% (Subagio 2008). Kadar protein mi basah menurut SNI 2987-2015 yaitu 6\% sedangkan kadar protein mi mocaf substitusi tepung jagung hanya sebesar $2,95 \%$ sehingga belum memenuhi syarat SNI.

Substitusi bahan lain dalam pembuatan mi mocaf terlihat signifikan perubahan proteinnya pada penambahan tepung lele. Penambahan tepung lele, tepung ubi jalar, dan tepung jagung menambah kadar protein tepung mocaf dan memenuhi standar SNI. Sedangkan penambahan tepung jagung pada pembuatan mi mocaf hanya memberi sedikit pertambahan protein dan belum memenuhi standar SNI.

\subsection{Brownies Tepung Mocaf}

Brownies merupakan salah satu jenis cake yang berwarna cokelat kehitaman. Brownies mempunyai tekstur lebih keras daripada cake karena brownies tidak membutuhkan pengembangan gluten (Cauvain dan Young, 2006). Brownies umumnya terbuat dari tepung terigu. Namun, sebagai upaya memanfaatkan komoditas pangan lokal maka tepung terigu disubstitusi dengan tepung mocaf. Mocaf adalah tepung dari ubi kayu (Manihot esculenta) yang diproses dengan cara fermentasi. Tepung di dalam adonan berfungsi sebagai pembentuk struktur dan tekstur brownies, pengikat bahan bahan lain, dan pendistribusi bahan-bahan lain secara merata, serta pembentuk citarasa (Matz, 1992). 
Tabel 3.3 Literatur tentang Persentase Kadar Protein pada Brownies dengan Berbagai Jenis Substitusi

\begin{tabular}{|c|c|c|}
\hline Sumber & Jenis Brownies & Kadar Protein $(\%)$ \\
\hline Putri, et al. (2015) & $\begin{array}{l}\text { Brownies mocaf dengan tepung } \\
\text { terigu }\end{array}$ & 1,06 \\
\hline Fizriani, et al. (2019) & $\begin{array}{l}\text { Brownies mocaf dengan tepung } \\
\text { kedelai hitam dan tepung jagung }\end{array}$ & 5,79 \\
\hline Nikawati, et al. (2019) & $\begin{array}{l}\text { Brownies mocaf dengan tepung koro } \\
\text { pedang }\end{array}$ & 8,73 \\
\hline Massytah, et al. (2019) & $\begin{array}{l}\text { Brownies mocaf dengan tepung } \\
\text { kacang merah }\end{array}$ & 6,87 \\
\hline
\end{tabular}

Merujuk pada Tabel 3.3, substitusi tepung mocaf pada brownies dengan bahan baku tepung terigu dapat mempengaruhi kadar protein dalam brownies. Hal tersebut terlihat pada hasil akhir penelitian yang dilakukan Putri, et al. (2015) menunjukan kadar protein terendah terdapat pada sampel brownies yang terdiri dari komposisi $40 \%$ tepung mocaf : $60 \%$ tepung terigu. Sedangkan kadar protein tertinggi terdapat pada sampel brownies yang dibuat dari $100 \%$ tepung terigu. Perbedaan kadar protein pada brownies tersebut disebabkan karena kadar protein yang terdapat dalam tepung mocaf lebih rendah yaitu sebesar $1,06 \%$, sedangkan kadar protein dalam tepung terigu sebesar 4\%. Rendahnya kadar protein pada tepung mocaf dibandingkan tepung terigu menurut Subagio (2007), kadar protein dalam tepung mocaf lebih rendah yaitu $1,2 \%$, sedangkan kadar protein pada tepung terigu lebih tinggi, yaitu sebesar 8-13\%.

Campuran bahan dasar brownies tepung mocaf dengan tepung kedelai hitam dan tepung jagung dapat meningkatkan kadar protein dalam produk brownies. Hal tersebut sesuai dengan penelitian Fizriani, et al. (2019) bahwa kandungan protein tertinggi pada brownies dengan bahan dasar 50\% tepung mocaf : 30\% tepung kedelai hitam : $20 \%$ tepung jagung yakni $(5,79 \pm 0,03)$ dan terendah yaitu pada brownies yang berbahan dasar $100 \%$ tepung mocaf $(4,72 \pm 0,08)$. Semakin banyak tepung kedelai yang ditambahkan maka semakin tinggi kandungan protein pada produk brownies.

Lama pemanggangan dan penambahan tepung koro pedang dapat mempengaruhi kadar protein pada brownies. Menurut Nikawati, et al. (2019), kadar protein tertinggi pada brownies yaitu $8,73 \%$ diperoleh pada perlakuan prosentase tepung koro dan tepung mocaf 30:70 dan pada waktu 60 menit. Sedangkan kadar protein paling rendah yaitu 6,13\% diperoleh dari perbandingan tepung koro dan tepung mocaf 50:50 dan waktu 45 dan 75 menit. Selain itu, suhu dapat mempengaruhi kadar protein pada brownies. Hal ini diperkuat oleh penelitian Dian (2015) bahwa penggunaan suhu yang terlalu tinggi dan lama pemanganggan dapat menyebabkan penurunan kadar protein.

Perbandingan bahan dasar brownies kukus gluten free casein free tepung mocaf dengan tepung kacang merah berpengaruh terhadap kadar protein. Hal tersebut sesuai dengan penelitian Massytah, et al. (2019) bahwa nilai tertinggi kadar protein pada brownies dengan perbandingan bahan dasar tepung mocaf dan tepung kacang merah 50:50, yaitu sebesar $6,87 \%$ dan terendah pada brownies dengan bahan dasar tepung mocaf $100 \%$, yaitu sebesar 3,21\%. Kandungan protein pada brownies kukus gluten free casein free tertinggi 
pada penambahan tepung kacang merah terbanyak karena kadar protein tepung kacang merah mencapai 19,27\% sedangkan kadar protein pada mocaf 4,07\%.

\subsection{Nugget Ayam Tepung Mocaf}

Nugget adalah suatu bentuk produk olahan daging yang terbuat dari daging giling yang diberi bumbu, dicampur bahan pengisi dan bahan pengikat berupa tepung, kemudian dicetak, dikukus, dan dilumuri perekat tepung (batter) yaitu campuran yang terdiri dari air, tepung, dan bumbu-bumbu yang digunakan utuk mencelupkan produk sebelum dimasak, lalu diselimuti tepung roti (breading) (Astawan, 2007). Penambahan bahan pengisi dan bahan pengikat berfungsi untuk meningkatkan stabilitas emulsi, mengurangi penyusutan saat pemasakan, meningkatkan karakteristik potongan, meningkatkan cita rasa, dan mengurangi biaya formulasi (Kusumaningrum, 2013).

Menurut Kusumanegara (2012), nugget komersial yang beredar di masyarakat diolah dengan menambahkan filler atau bahan pengisi. Umumnya, tepung terigu digunakan sebagai bahan pengisi nugget. Tepung mocaf merupakan salah satu alternatif pangan lokal yang dapat digunakan sebagai filler karena memiliki kandungan pati yang cukup tinggi yaitu berkisar $85 \%$ sampai $87 \%$ (Ariyani, 2010). Fitriadenti (2011), menyatakan bahwa sebanyak $80 \%$ tepung mocaf dapat mensubstitusi tepung terigu sebagai filler dalam pembuatan nugget.

Tabel 3.4 Literatur tentang Persentase Kadar Protein pada Nugget dengan Berbagai Jenis Substitusi

\begin{tabular}{llc}
\hline \multicolumn{1}{c}{ Sumber } & \multicolumn{1}{c}{ Jenis Nugget } & Kadar Protein (\%) \\
\hline Nugraha (2019) & $\begin{array}{l}\text { Filler tepung mocaf 10\% } \\
\text { Kusnia (2018) }\end{array}$ & $\begin{array}{l}\text { Filler tepung mocaf 50\% substitusi } \\
\text { tepung tapioka }\end{array}$ \\
Hanifa (2014) & $\begin{array}{l}\text { Filler tepung mocaf 10\% substitusi } \\
\text { tepung terigu }\end{array}$ & 10,99 \\
Hanifa (2014) & $\begin{array}{l}\text { Filler tepung mocaf 10\% substitusi } \\
\text { tepung terigu dengan penambahan } \\
\text { tepung tulang rawan 15\% }\end{array}$ & 18,19 \\
& & \\
\hline
\end{tabular}

Merujuk pada Tabel 3.4, berdasarkan penelitian Nugraha (2019), hasil analisis uji kadar protein pada nugget ayam dengan filler tepung mocaf $10 \%$ memiliki kadar protein sebesar $14.17 \pm 0,20 \%$. Kadar protein paling tinggi diperoleh dari filler tepung mocaf jika dibandingkan dengan perlakuan lain yaitu dengan filler tepung terigu, maizena, dan tapioka. Hal tersebut karena tepung mocaf memiliki karakteristik yang berbeda. Kandungan protein pada tepung terjadi proses gelatinisasi yang sempurna. Proses gelatinisasi yang sempurna melibatkan pengikatan air oleh jaringan yang dibentuk rantai molekul protein (Komariah et al., 2005).

Menurut penelitian Kusnia (2018), hasil analisis uji kadar protein menunjukkan bahwa substitusi tepung mocaf $50 \%$ dengan tepung tapioka sebagai filler memiliki kadar protein sebesar $10,88 \%$. Hasil penelitian menunjukkan bahwa substitusi mocaf tidak berpengaruh nyata $(\mathrm{P}>0,05)$ terhadap kadar protein nugget ayam dimana dengan penambahan mocaf 
lebih cenderung naik karena semakin banyak mocaf yang disubstitusikan terhadap tepung tapioka.

Menurut penelitian Hanifa (2014) hasil analisis uji kadar protein menunjukkan bahwa penggunaan tepung mocaf (10\%) sebagai substitusi tepung terigu memiliki kadar protein sebesar $18,19 \%$. Kadar protein tersebut $>12 \%$ sehingga telah sesuai standar kadar protein dalam nugget menurut SNI yaitu minimal $12 \%$ b/b (BSN, 2002). Hasil analisis uji kadar protein pada nugget ayam dengan penambahan tepung tulang rawan $15 \%$ menunjukkan hasil 18,70\%. Penambahan $15 \%$ tepung tulang rawan pada nugget ayam dapat meningkatkan kadar protein sebesar 7,5\%. Semakin tinggi tepung tulang rawan yang ditambahkan maka kadar protein pun semakin tinggi. Hal tersebut dikarenakan tepung tulang rawan memiliki kandungan protein yang cukup tinggi, yaitu 71,93\% (Hardianto, 2002).

\section{Kesimpulan}

Pada pembuatan cookies mocaf dengan rasio perbandingan tepung mocaf dan tepung tempe sebesar 75:25 menghasilkan kadar protein paling tinggi yaitu sebesar 9,09 $\pm 0,22 \%$. Pada pembuatan mi mocaf dengan komposisi 25\% terigu, $40 \%$ mocaf, $20 \%$ tapioka, dan $15 \%$ tepung lele menghasilkan kadar protein paling tinggi yaitu sebesar $14,65 \pm 0,19 \%$. Pada pembuatan brownies mocaf dengan perbandingan tepung mocaf dan tepung koro sebesar 70:30 menghasilkan kadar protein paling tinggi yaitu sebesar 8,73\%. Pada pembuatan nugget ayam dengan tepung mocaf $10 \%$ mensubstitusi tepung terigu dan penambahan tepung tulang rawan $15 \%$ menghasilkan kadar protein paling tinggi yaitu sebesar $18,70 \%$.

\section{Ucapan Terima Kasih}

Penulis menyampaikan terima kasih kepada Prodi Pendidikan Teknologi Agroindustri selaku fasilitator dan pihak-pihak terlibat yang senantiasa memberikan dukungan selama proses pembuatan artikel review ini.

\section{Pustaka}

Aliya, L.S., Yosfi Rahmi, Setyawati Soeharto. 2016. "Mi "Mocafle” Peningkatan Kadar Gizi Mie Kering Berbasis Pangan Lokal Fungsional (Mocafle Noodle to Increase the Nutritional Level of Dry Noodles as Fuctional Local Food Based)", dalam Indonesian Journal of Human Nutrition. Volume 3 (1), 2016, 32-41.

Alvionita, V., Angkasa, D., dan Wijaya, H. 2017. "Pembuatan Cookies Bebas Gluten Berbahan Tepung Mocaf dan Tepung Beras Pecah Kulit dengan Tambahan Sari Kurma", dalam Jurnal Pangan dan Gizi. Volume 7 (2), 2017, 72-81.

Ariyani, N. 2010. Formulasi tepung campuran siap pakai berbahan dasar tapiokamocal dengan penambahan maltodekstrin serta aplikasinya sebagai tepung pelapis keripik bayam. Skripsi Sarjana Pertanian. Purwokerto: Fakultas Pertanian, Universitas Jenderal Soedirman.

Astawan, M. 2007. Panduan Karbohidrat Terlengkap. Jakarta: Dian Rakyat 
Badan Perencanaan Pembangunan Nasional. 2007. Rencana Aksi Nasional Pangan dan Gizi. Jakarta: Bappenas.

Badan Standardisasi Nasional. 1996. SNI 01-2974-1996 Mi Kering. Jakarta: Badan Standardisasi Nasional.

Cauvain, Stanley P dan Linda S Young. 2006. Baked products: Science, Technology and Practice. Garsington Road: Blackwell Publishing Ltd.

Departemen Kesehatan Republik Indonesia. 2009. Daftar Komposisi Bahan Makanan. Jakarta: Departemen Kesehatan Republik Indonesia.

Dian, S., Almasyhuri, dan Lamid, A. 2015. "Pengaruh proses pemasakan terhadap komposisi zat gizi bahan pangan sumber protein", dalam Pusat Biomedis dan Teknologi Dasar Kesehatan. Volume 25 (4), 2015, 235-242.

Diniyah, N., Setiawati, D., Windrati, W. S., dan Subagio, A. 2018. "Karakterisasi Mie Mojang (Mocaf-jagung) dengan Perbedaan Jenis dan Konsentrasi Bahan Pengikat", dalam Jurnal Penelitian Pascapanen Pertanian. Volume 14 (2), 2017, 98-107.

Fitasari E. 2009. "Pengaruh Penambahan Tepung Terigu Terhadap Kadar Air, Kadar Lemak, Kadar Protein, Mikrostruktur, dan Mutu Organoleptik Keju Gouda Olahan”, dalam J. Ilmu dan Teknologi Hasil Ternak. Volume 4 (2), 2009, 17-29.

Fitriadenti, M. J. 2011. Kualitas Fisik dan Sensoris Chicken Nugget dengan Substitusi Filler Tepung Mocaf (Modified Cassava Flour). Skripsi. Yogyakarta: Fakultas Peternakan, Universitas Gadjah Mada.

Fizriani, A., Putri, N. E., dan Triandita, N. 2019. "Sifat Kimia dan Sensori Brownies Berbahan Baku Tepung Mocaf, Jagung Dan Kedelai Hitam”, dalam FoodTech: Jurnal Teknologi Pangan. Volume 2 (2), 2019, 24-34.

Hanifa, R. 2014. "Kadar Protein, Kadar Kalsium, Dan Kesukaan Terhadap Cita Rasa Chicken Nugget Hasil Substitusi Terigu Dengan Mocaf Dan Penambahan Tepung Tulang Rawan”, dalam Jurnal Pangan dan Gizi. Volume 4(2), 2014.

Hardianto, V. 2002. Pembuatan Tepung Tulang Rawan Ayam Pedaging Menggunakan Pengering Drum (Drum Dym) dengan Penambahan Bahan Pemutih (Bleaching Agent). Skripsi. Bogor: Fakultas Peternakan, Institut Pertanian Bogor.

Haryadi. 2006. Teknologi Pengolahan Beras. Yogyakarta: Gadjah Mada University Press.

Herawati, et al. 2018. "Cookies Tepung Beras Merah (Oryza nivara) - Mocaf (Modified Cassava Flour) dengan Penambahan Bubuk Kayu Manis (Cinnamomun burmanni)", dalam Jurnal Teknologi dan Industri Pangan. Volume 3 (1), 2018, 33-40.

Hersoelistyorini, W., Dewi, S. S., dan Kumoro, A. C. 2015. "Sifat Fisikokimia dan Organoleptik Tepung Mocaf (Modified Cassava Flour) dengan Fermentasi Menggunakan Ekstrak Kubis", dalam The 2nd University Research Coloquium. 2015, 10-17.

Indrianti, N., Kumalasari, R., Ekafitri, R. dan Darmajana, D.A. 2013. "Pengaruh Penggunaan Pati Ganyong, Tapioka, dan Mocaf Sebagai Bahan Substitusi Terhadap Sifat Fisik Mie Jagung Instan”, dalam Agritech. Volume 33 (4), 2013, 391-398.

Khalil, A. 2006. "Nutritional Improvement of an Egyptyan Breed Of Mung Bean by Probiotic Lactobacill", dalam African Journal of Biotechnology. Volume 5. 
Komariah, N., Ulupi, dan E. N. Hedrarti. 2005. Sifat Fisik Daging Ayam dan Jamur Tiram Putih sebagai Campuran Bahan Dasar. Bogor: Fakultas Peternakan IPB.

Kristanti, D., Setiaboma, W., dan Herminiati, A. 2020. "Karakteristik Fisikokimia dan Organoleptik Cookies Mocaf dengan Penambahan Tepung Tempe (Physicochemical and Organoleptic Characteristics of Mocaf Cookies with Tempeh Flour Additions)", dalam Biopropal Industri. Volume 11 (1), 2020, 1-8.

Kusnia, N. 2018. Pengaruh Substitusi Tepung Tapioka dengan Mocaf (Modified Cassava Flour) Terhadap Mutu Kadar Protein, Lemak, Abu, Karbohidrat pada Nugget Ayam. Doctoral dissertation, Universitas Brawijaya.

Kusumanegara, A.cI., dan Erwanto, Y. 2012. "Kualitas Fisik, Sensoris dan Kadar Kolesterol Nugget Ampela dengan Imbangan Filler Tepung Mocaf yang Berbeda", dalam Buletin Peternakan. Volume 36 (1), 2012, 19-24.

Kusumaningrum, M., Kusrahayu, K., dan Mulyani, S. 2013. "Pengaruh berbagai filler (bahan pengisi) terhadap kadar air, rendemen dan sifat organoleptik (warna) chicken nugget", dalam Animal Agriculture Journal. Volume 2 (1), 2013, 370-376.

Mahardika, F. 2015. Pengaruh Imbangan Tepung Mocaf (Modified Cassava Flour) dan Tepung Kacang Hijau (Phaseolus radiatus L.) Terhadap Sifat Organoleptik Cookies Mocaf. Karya Tulis Ilmiah.

Massytah, H. A., Ekawati, I. G. A., dan Wisaniyasa, N. W. 2019. "Perbandingan Mocaf Dengan Tepung Kacang Merah Dalam Pembuatan Brownies Kukus Gluten Free Casein Free (GFCF)", dalam Jurnal Ilmu dan Teknologi Pangan (ITEPA). Volume 8 (1), 2019, 1-7.

Matz SA. 1992. Bakery Technology and Engineering 3rd Ed. Texas: Pan tech International Inc.

Maulida, M. H. 2016. Pengaruh Penambahan Puree Daun Kelor Dan Bubuk Daun Kelor Terhadap Hasil Jadi Mie Kering Mocaf. Skripsi. Surabaya: Universitas Negeri Surabaya.

Muhandri, C., Zulkhaiar, H., Subarna, B., dan Nurtama. 2012. "Komposisi Kimia Tepung Jagung Varietas Unggul Lokal Dan Potensinya Untuk Pembuatan Mi Jagung Menggunakan Ekstruder Pencetak", dalam J. Sains Terapan. Volume 2 (1), 2012, 16-31.

Naurah. 2013. "Indeks Glisemik Kacang-Kacangan”, dalam Jurnal Teknologi dan Industri Pangan. Volume 13 (3), 2002, 51-56.

Nikawati, T., Widanti, Y. A., dan Mustofa, A. 2019. "Brownies Bebas Gluten dari Tepung Koro Pedang (Canavalia ensiformis L) dengan Substitusi Tepung Mocaf dan Variasi Lama Pemanggangan", dalam Jurnal Teknologi Hasil Pertanian. Volume 12 (2), 2019, 99-106.

Nugraha, B.D. dan Iswoyo, A.S. 2019. "Sifat Fisiokimia dan Oganoleptik Nugget Ayam dengan Penambahan Jenis Tepung yang Berbeda (The Nature Of Fisiokimia and Organoleptik with Other Types Of Flour The Chiken Nuggets Are Different)".

Nurjannah, H. 2019. Formulasi Mie Mocaf dengan Pewarna Alami Ubi Jalar Ungu. Doctoral dissertation, Institut Kesehatan Helvetia. 
Oktaviana, A.S., Hersoelistyorini, W., dan Nurhidajah, N. 2017. "Kadar Protein, Daya Kembang, dan Organoleptik Cookies dengan Substitusi Tepung Mocaf dan Tepung Pisang Kepok", dalam Jurnal Pangan dan Gizi. Volume 7c (2), 2017, 72-81.

Putri, A. E. V. T., Pratjojo, W., dan Susatyo, E. B. 2015. "Uji Proksimat dan Organoleptik Brownies dengan Substitusi Tepung Mocaf (Modified Cassava Flour), dalam Indonesian Journal of Chemical Science. Volume 4 (3), 2015.

Rahayu, W.P., Pambayun, R., Santoso, U., Nuraida, L. dan Ardiansyah, A. 2015. "Tinjauan Ilmiah Teknologi Pengolahan Tempe Kedelai".

Ramadhan, A., dan Sari, E.R.. 2015. "Variasi Perbandingan Tepung Terigu dan Mocaf (Modified Cassava Flour) dalam Pembuatan Mie Mocaf", dalam AGRITEPA: Jurnal Ilmu dan Teknologi Pertanian. Volume 2 (1), 2015.

Setiavani, Gusti. 2013. "Studi Pembuatan Mie Mocaf dengan Penambahan Tepung Ampas Tahu Fermentasi Terhadapat Nilai Gizi dan Tingkat Penerimaan Konsumen".

Subagio, A. 2007. Industrialisasi Modified Cassava Flour (MOCAF) Sebagai Bahan Baku Industri Pangan Untuk Menunjang Diverifikasi Pangan Pokok Nasional. Jember: Fakultas Teknologi Pertanian, Universitas Jember.

Subagio, A., Windrati, W. S., Witono, Y., Fahmi. 2008. Prosedur Operasi Standar (POS):

Produksi MOCAF Berbasis Klaster. Jakarta: Kementrian Negara Riset dan Teknologi.

Sugiyono. 2015. Metode Penelitian Pendidikan. Bandung: Alfabeta.

Suyanti. 2010. Membuat Mie Sehat: Bergizi dan Bebas Pengawet. Jakarta: Penebar Swadaya.

Syarief, R., dan Anies I. 1988. Pengetahuan Bahan untuk Industri Pertanian.Mediyatama Sarana Perkasa. Jakarta.

Turisyawati R. 2011. Pemanfaatan Tepung Suweg (Amorphopallus campanulatus) Sebagai Tepung Terigu Pada Pembuatan Cookies. Skripsi. Semarang: Universitas Negeri Semarang.

Welli, Y. 2012. "Pemanfaatan Umbi Talas Sebagai Bahan Subsitusi Tepung Terigu dalam Pembuatan Cookies yang Disuplementasi dengan Kacang Hijau", dalam Jurnal Matematika. Volume 13 (2), 2012, 94-106.

Widiantara, T. 2018. "Kajian Perbandingan Tepung Kacang Koro Pedang (Canavalia Ensiformis) Dengan Tepung Tapioka Dan Konsentrasi Kuning Telur Terhadap Karakteristik Cookies Koro", dalam Pasundan Food Technology Journal (PFTJ). Volume 5 (2), 2018, 146-153.

Winarno, F.G. 2009. Kimia Pangan dan Gizi. Jakarta: Gedia Pustaka Utama.

Yuliyandjaja, J.P., Widayat, W., Hadiyanto, H., Suzery, M., dan Budianto, I.A. 2020. Diversifikasi Tepung Mocaf Menjadi Produk Mie Sehat di PT. Tepung Mocaf Solusindo", dalam Indonesia Journal of Halal. Volume 2 (2), 2020, 40-45. 